\title{
Chemical Constituents of Dracontomelon Dao (Blanco) Merr. et Rolfe
}

\author{
Consolacion Y. Ragasa ${ }^{1,2,{ }^{*}}$,Tyson C. Batarra' ${ }^{1}$, Julius Leonard A. Vivar ${ }^{1}$, Mariquit M. De Los Reyes ${ }^{3}$, \\ and Chien-Chang Shen ${ }^{4}$
}

\section{Consolacion Y. Ragasa ${ }^{1,2, *}$, Tyson C. Batarra', Julius Leonard A. Vivar ${ }^{1}$, Mariq- uit M. De Los Reyes ${ }^{3}$, and Chien-Chang Shen ${ }^{4}$}

'Chemistry Department, De La Salle University, 2401 Taft Avenue, Manila 1004, PHILIPPINES.

${ }^{2}$ Chemistry Department, De La Salle University Science \& Technology Complex Leandro V. Locsin Campus, Biñan City, Laguna 4024, PHILIPPINES. ${ }^{3}$ Biology Department, De La Salle University, 2401 Taft Avenue, Manila 1004, PHILIPPINES.

${ }^{4}$ National Research Institute of Chinese Medicine, Ministry of Health and Welfare, 155-1, Li-Nong St., Sec. 2, Taipei 112, TAIWAN.

\section{Correspondence}

Consolacion Y. Ragasa, Chemistry Department, De La Salle University, 2401 Taft Avenue, Manila 1004, Philippines \& Chemistry Department, De La Salle University Science \& Technology Complex Leandro V. Locsin Campus, Biñan City, Laguna 4024 . PHILIPPINES.

Tel/Fax: (+0632) 5360230

E-mail: consolacion.ragasa@dlsu.edu.ph

History

- Submission Date: 01-05-2017;

- Review completed: 18-05-2017;

- Accepted Date: 08-06-2017

DOI : 10.5530/pj.2017.5.103

Article Available online

http://www.phcogj.com/v9/i5

Copyright

(C) 2017 Phcog.Net. This is an openaccess article distributed under the terms of the Creative Commons Attribution 4.0 International license.

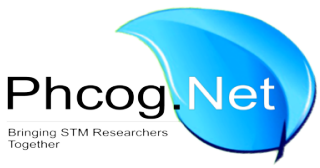

\begin{abstract}
Introduction: The leaves, twigs and flowers of Dracontomelon dao (Blanco) Merr. et Rolfe, an indigenous Philippine tree were investigated for their chemical constituents. Methods: The compounds were isolated by silica gel chromatography and their structures were identified by NMR spectroscopy. Results: Chemical investigation of $D$. dao led to the isolation of cardol (1), $\beta$-sitosteryl-3 $\beta$-glucopyranoside-6, O-fatty acid esters (2), $\beta$-sitosteryl fatty acid esters (3), and a mixture of $\beta$-sitosterol (4a) and stigmasterol (4b) from the petiole; $\mathbf{1}$, a mixture of 4 a and 4b, anacardic acid (5), triacylglycerols (6), monoacylglycerol (7), long-chain fatty acid esters (8), and linoleic acid (9) from the twigs; and a mixture of $\mathbf{4 a}$ and $\mathbf{4 b}, \mathbf{5}, \mathbf{6}, \mathbf{8}$, long-chain fatty alcohols (10), and long- chain hydrocatbons (11) from the flowers of $D$. dao. The structures of $\mathbf{1}$ and $\mathbf{5}$ were elucidated by extensive 1D and 2D NMR spectroscopy, while those of $\mathbf{2 - 4}$ and 6-11 were identified by NMR spectroscopy. Conclusion: This is the first report on the isolation of $\mathbf{1}, \mathbf{4 b}$ and 6-9 from $D$. dao.

Key words: Dracontomelon Dao (Blanco) Merr. et Rolfe, Anacardaceae, Cardol, Anacardic Acid, 3-Alkylphenols, B-Sitosteryl-3 $\beta$-Glucopyranoside-6'-O-Fatty Acid Esters, B-Sitosteryl Fatty Acid Esters.
\end{abstract}

\section{INTRODUCTON}

Dracontomelon dao (Blanco) Merr. et Rolfe of the family Anacardiaceae, locally known as dao is an indigenous Philippine tree which is also widely distributed throughout the South and Southeast Asia. ${ }^{1}$ The dao bark is used against dysentery. The mature fruits and kernel of the seeds are edible, while the flowers and young leaves are eaten as vegetables. The wood of dao is employed in light construction, timber and firewood. ${ }^{2}$ The EtOAc extract of the leaves of $D$. dao was observed to exhibit strong anti-bacterial activity with an $\mathrm{IC}_{50}$ of $98.5 \mu \mathrm{g} / \mathrm{mL}$. $^{3}$ The crude methanolic extracts of the leaves, stem and root barks of $D$. dao exhibited a very good level of broad spectrum antibacterial activity, while the leaf extract exhibited antifungal activity. ${ }^{4}$ The essential oil was extracted from the skins of stem of $D$. dao by steam distillation. GC-MS analysis identified 13 compounds with the following major components: n-hexadecanoic acid (46.13\%), octadecanoic acid (15.44\%), (E)-9-octadecenoic acid (13.73\%), and $(Z, Z)-9,12$-octadecadienoic acid $(7.79 \%){ }^{5}$

We earlier reported the isolation of anacardic acid, $\beta$-sitosteryl-3 $\beta$-glucopyranoside-6'-O-fatty acid esters, $\beta$-sitosterol, phytol, phytyl fatty acid esters, $\beta$-sitosteryl fatty acid esters, chlorophyll a, squalene, long-chain fatty alcohols, and long-chain hydrocarbons from the leaves of $D$. dao. ${ }^{6}$ We report herein the isolation ofcardol (1), $\beta$-sitosteryl-3 $\beta$-glucopyranoside-6, $O$-fatty acid esters (2), $\beta$-sitosteryl fatty acid esters (3), and a mixture of $\beta$-sitosterol (4a) and stigmasterol (4b) from the petiole; 1,anacardic acid (5), a mixture of $4 \mathbf{a}$ and 4b, triacylglycerols (6), monoacylglycerol (7), longchain fatty acid esters (8) and linoleic acid (9) and from the twigs; and 4a-6, 8, long-chain fatty alcohols (10), and long chain-hydrocatbons (11) from the flowers of $D$. dao. The structures of 1-9 are presented in Figure 1. To the best of our knowledge this is the first report on the isolation of $\mathbf{1}, \mathbf{4 b}$ and 6-9 from $D$. dao.

\section{MATERIALS AND METHODS}

\section{General Experimental Procedure}

NMR spectra were recorded on a Varian VNMRS spectrometer in $\mathrm{CDCl}_{3}$ at $600 \mathrm{MHz}$ for ${ }^{1} \mathrm{H} \mathrm{NMR}$ and $150 \mathrm{MHz}$ for ${ }^{13} \mathrm{C}$ NMR spectra. Column chromatography was performed with silica gel 60 (70-230 mesh). Thin layer chromatography was performed with plastic backed plates coated withsilica gel $\mathrm{F}_{254}$ and the plates were visualized by spraying with vanillin $/ \mathrm{H}_{2} \mathrm{SO}_{4}$ solution followed by warming.

\section{Sample Collection}

Samples of the petiole, twigs and flowers of Dracontomelon dao (Blanco) Merr. et Rolfe were collected from De La Salle University - Science and Technology Complex (DLSU-STC) Complex Leandro V. Locsin Campus, Biñan City, Laguna, Philippines in March 


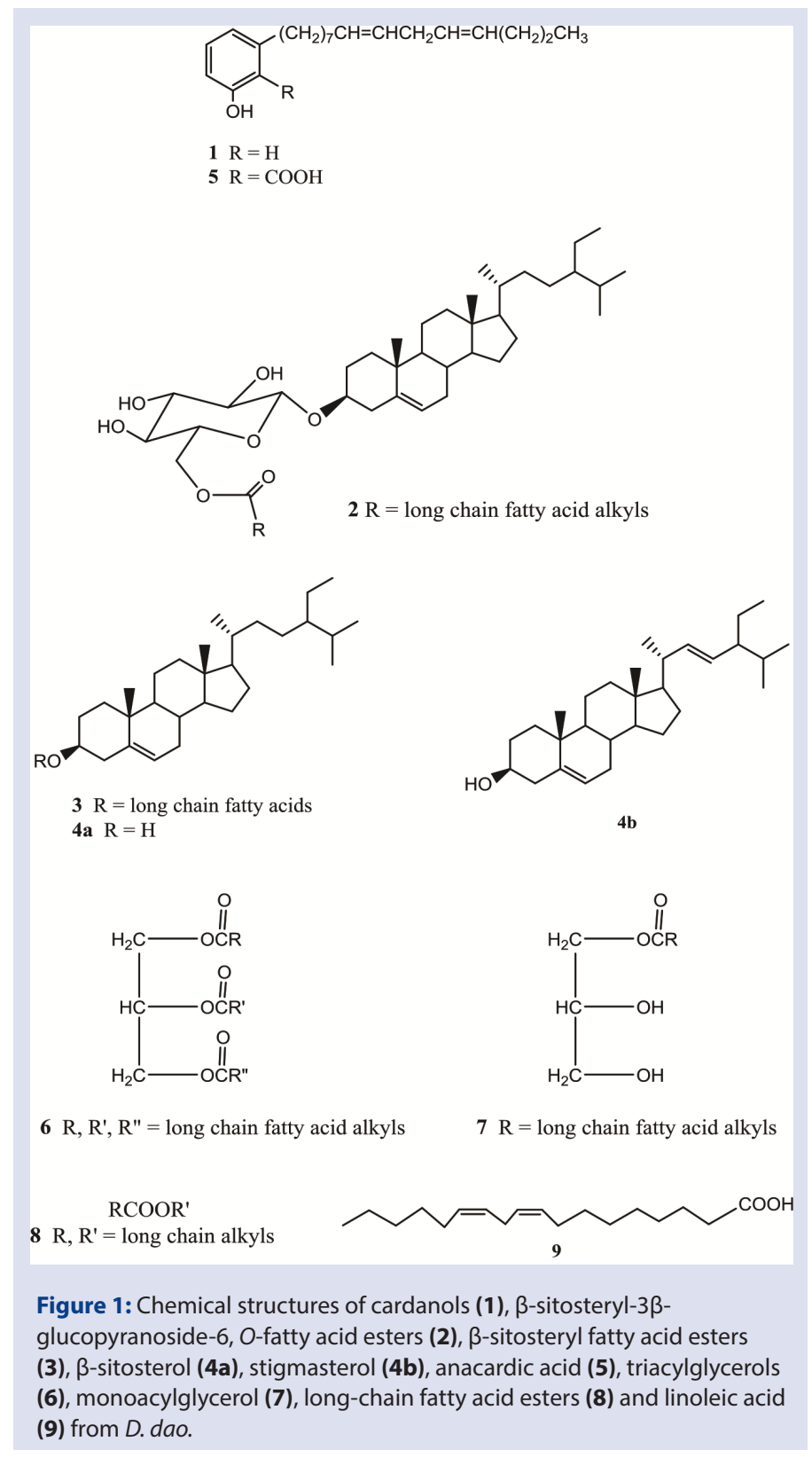

2016. The samples were authenticated at the Botany Division, Philippine National Museum.

\section{General Isolation Procedure}

A glass column 12 inches in height and 0.5 inch internal diameter was used for the chromatography. The crude extracts were fractionated by silica gel chromatography using increasing proportions of acetone in $\mathrm{CH}_{2} \mathrm{Cl}_{2}$ at $10 \%$ increment by volume as eluents. Five milliliter fractions were collected. All fractions were monitored by thin layer chromatography. Fractions with spots of the same $R f$ values were combined and rechromatographed in appropriate solvent systems until TLC pure isolates were obtained. Final purifications were conducted using Pasteur pipettes as columns. One milliliter fractions were collected.

\section{Isolation of the chemical constituents from the petole of D. dao}

The air-dried $D$. dao petiole (179.3 g) were ground in a blender, soaked in $\mathrm{CH}_{2} \mathrm{Cl}_{2}$ for 3 days and then filtered. The solvent was evaporated under vacuum to afford a crude extract $(0.90 \mathrm{~g})$ which was chromatographed using increasing proportions of acetone in $\mathrm{CH}_{2} \mathrm{Cl}_{2}$ at $10 \%$ increment by volume. The $10 \%$ acetone in $\mathrm{CH}_{2} \mathrm{Cl}_{2}$ fraction was rechromatographed $(2 \times)$ using $1 \%$ EtOAc in petroleum ether to afford 3 (2 mg). The first 30\% acetone in $\mathrm{CH}_{2} \mathrm{Cl}_{2}$ fraction was rechromatographed using 10\% EtOAc in petroleum ether. The less polar fractions were combined and rechromatographed using 10\% EtOAc in petroleum ether to afford $1(4 \mathrm{mg})$. The second $30 \%$ acetone in $\mathrm{CH}_{2} \mathrm{Cl}_{2}$ fraction was rechromatographed using $15 \%$ EtOAc in petroleum ether to yield $\mathbf{4 a}$ and $\mathbf{4 b}(3 \mathrm{mg})$ after washing with petroleum ether. The $60 \%$ acetone in $\mathrm{CH}_{2} \mathrm{Cl}_{2}$ fraction was rechromatographed $(3 \times)$ using $\mathrm{CH}_{3} \mathrm{CN}: \mathrm{Et}_{2} \mathrm{O}: \mathrm{CH}_{2} \mathrm{Cl}_{2}(1: 1: 8, \mathrm{v} / \mathrm{v})$ to afford $2(3 \mathrm{mg})$ after washing with petroleum ether.

\section{Isolation of the chemical constituents from the twigs of D. dao}

The air-dried $D$. dao twigs ( $87 \mathrm{~g}$ ) were ground in a blender, soaked in $\mathrm{CH}_{2} \mathrm{Cl}_{2}$ for 3 days and then filtered. The solvent was evaporated under vacuum to afford a crude extract $(0.30 \mathrm{~g})$ which was chromatographed using increasing proportions of acetone in $\mathrm{CH}_{2} \mathrm{Cl}_{2}$ at $10 \%$ increment by volume. The $\mathrm{CH}_{2} \mathrm{Cl}_{2}$ fraction was rechromatographed using petroleum ether. A second rechromatography was conducted using $1 \%$ EtOAc in petroleum ether to yield $8(2 \mathrm{mg})$. The $10 \%$ acetone in $\mathrm{CH}_{2} \mathrm{Cl}_{2}$ fraction was rechromatographed by gradient elution using $5 \%$ EtOAc in petroleum ether; followed by $10 \%$ EtOAc in petroleum ether; then $15 \%$ EtOAc in petroleum ether; and finally $20 \%$ EtOAc in petroleum ether. The fractions eluted with 5\% EtOAc in petroleum ether were combined and rechromatographed using the same solvent to afford $\mathbf{1}(2 \mathrm{mg})$ and $\mathbf{9}(3 \mathrm{mg})$. The fractions eluted with $15 \%$ EtOAc in petroleum ether were combined and rechromatographed using the same solvent to yielda mixture of $\mathbf{4 a}$ and $\mathbf{4 b}(6 \mathrm{mg})$ after washing with petroleum ether. The fractions eluted with $20 \%$ EtOAc in petroleum ether were combined and rechromatographed using the same solvent to afford $6(4 \mathrm{mg})$. The $30 \%$ acetone in $\mathrm{CH}_{2} \mathrm{Cl}_{2}$ fraction was rechromatographed using 20\% EtOAc in petroleum ether. The less polar fractions were rechromatographed using $\mathrm{CH}_{2} \mathrm{Cl}_{2}$ to yield $5(3 \mathrm{mg})$ after washing with petroleum ether. The more polar fractions yielded 7 (2 mg) after washing with petroleum ether.

\section{Isolation of the chemical constituents from the flowers of D. dao}

The air-dried $D$. dao flowers ( $19 \mathrm{~g}$ ) were ground in a blender, soaked in $\mathrm{CH}_{2} \mathrm{Cl}_{2}$ for 3 days and then filtered. The solvent was evaporated under vacuum to afford a crude extract $(0.300 \mathrm{~g})$ which was chromatographed using increasing proportions of acetone in $\mathrm{CH}_{2} \mathrm{Cl}_{2}$ at $10 \%$ increment by volume. The $\mathrm{CH}_{2} \mathrm{Cl}_{2}$ fraction was rechromatographed using petroleum ether $(2 \times)$ to afford $\mathbf{1 1}(5 \mathrm{mg})$ after washing with petroleum ether. The $10 \%$ acetone in $\mathrm{CH}_{2} \mathrm{Cl}_{2}$ fraction was rechromatographed using $1 \% \mathrm{EtOAc}$ in petroleum ether to yield $\mathbf{6}(3 \mathrm{mg})$ and $\mathbf{8}(4 \mathrm{mg})$. The $20 \%$ acetone in $\mathrm{CH}_{2} \mathrm{Cl}_{2}$ fraction was rechromatographed using $5 \%$ EtOAc in petroleum ether to afford $10(5 \mathrm{mg})$ and a mixture of $4 \mathbf{a}$ and $4 \mathbf{b}(6 \mathrm{mg})$ after washing with petroleum ether. The $30 \%$ to $50 \%$ acetone in $\mathrm{CH}_{2} \mathrm{Cl}_{2}$ fractions were combined and rechromatographed $(3 \times)$ using $20 \%$ EtOAc in petroleum ether to yield 5 (12 $\mathrm{mg}$ ) after washing with petroleum ether.

\section{RESULTS AND DISCUSSION}

Silica gel chromatography of the dichloromethane extracts of $D$. dao yielded 1-11. The NMR spectra of $\mathbf{1}$ are in accordance with data reported in the literature forcardanol; 72 for $\beta$-sitosteryl-3 $\beta$-glucopyranoside-6'$O$-fatty acid esters; ${ }^{8} \mathbf{3}$ for $\beta$-sitosteryl fatty acid ester; ${ }^{9} \mathbf{4}$ a for $\beta$-sitosterol; ${ }^{10}$ 4b for stigmasterol; $;{ }^{10} 5$ for anacardic acid; $;{ }^{11} 6$ for triacylglycerols; ${ }^{12} 7$ for monoacylglycerol; ${ }^{10} \mathbf{8}$ for long-chain fatty acid esters; ${ }^{13} \mathbf{9}$ for linoleic acid; ${ }^{14} \mathbf{1 0}$ for long-chain fatty alcohols; ${ }^{15}$ and $\mathbf{1 1}$ for long-chain hydrocarbons. ${ }^{16}$

\section{CONCLUSION}

The petiole, twigs, flowers and leaves of $D$. dao afforded phenolics, sterols and lipids. The following compounds were obtained from the 
different parts of the tree: cardol (1) from the petiole; $\beta$-sitosteryl-3 $\beta$ glucopyranoside-6'-O-fatty acid esters (2) from the petiole and leaves; $\beta$-sitosteryl fatty acid esters (3) from the petiole; $\beta$-sitosterol (4a) from the petiole, twigs, flowers and leaves; stigmasterol from the petiole, twigs and flowers; anacardic acid (5) from the twigs, flowers and leaves; triacylglycerols (6) from the twigs and flowers; monoacylglycerol (7) from the twigs; long-chain fatty acid esters (8) from the twigs and flowers; linoleic acid (9) from the twigs; long-chain fatty alcohols (10) and longchain hydrocarbons (11) from the flowers.

\section{ACKNOWLEDGEMENT}

A research grant from the Science Foundation through the URCO is gratefully acknowledged.

\section{CONFLICT OF INTEREST}

There is no conflict of interest.

List of Abbreviations: NMR - Nuclear Magnetic Resonance, EtOAc Ethyl acetate, $\mathrm{Et}_{2} \mathrm{O}-$ Diethyl ether.

\section{REFERENCES}

1. Goeltenboth F, Goeltenboth A. Agroecological comparison of „rainforestation” farming sites on Leyte, Philippines. Proceedings Dt. Tropentag 2000. 2000:84-5.

2. Dao | GreeninPhiippines - RAFl.org.ph. Downloaded from rafi.org.ph/greeninphilippines/green-almanac/dao/ on October 22, 2016.

3. Liu S, Zhao Y, Zeng N, Liu T, Zhang Y, et al. Anti-bacterial effect of four extracts from leaves of Dracontomelon dao on Escherichia coli growth using microcalo- rimetry coupled with principal component analysis. Journal of Thermal Analysis and Calorimetry. 2014;116(1):491-7.

4. Khan MR, Omoloso AD. Antibacterial and antifungal activities of Dracontomelon dao. Fitoterapia. 2002;73(4):327-30

5. Su XF, Liang ZY, Zhang YX. Study on the chemical constituents of essential oil from the skins of stem of Dracontomelon dao (Blanco) Merr. et Rolfe $[\mathrm{J}]$. Lishizhen Medicine and Materia Medica Research. 2008;7:045.

6. Ragasa CY, Vivar JLA, De Los Reyes MM, van Altena IA. Secondary metabolites from Dracontomelon dao (Merr. \& Rolfe). Der Pharma Chemica. 2016;8(19):257-60.

7. Julis J, Bartlett SA, Baader S, Beresford N, Routledge EJ, et al. Selective ethenolysis and oestrogenicity of compounds from cashew nut shell liquid. Green Chemistry. 2014;16(5):2846-56.

8. NgVAS, Agoo EMG, Shen C-C, Ragasa CY. Chemical constituents of Cycassanctilasallei. J Appl Pharm Sci. 2015;5(Suppl 1):12-17.

9. Ragasa CY, Ebajo V, De Los Reyes MM, MandiaEH, et al. Chemical constituents of Cordia dichotoma G. Forst. J Appl Pharm Sci. 2015;5(Suppl 2):16-21.

10. Ragasa CY, Lorena GS, Mandia EH, Raga DD, Shen C-C. Chemical constituents of Abrus precatorius. Amer J Essent Oils Nat Prod. 2013;1(2):7-10.

11. Ragasa CY, Borja D, Bassig R, Rideout JA. Antifungal compounds from Anacardium occidentale. Philipp J Sci. 2002;131(1):9-15.

12. Ragasa CY, Caro J, Shen C-C. Chemical constituents of Artocarpus ovatus Blanco. Der Pharma Chemica. 2015;7(2):178-82.

13. Radulovic NS, Zlatkovic DB. n-Octyl esters of long-chain fatty acids are not anthropogenic pollution markers. Environmental Chemistry Letters 2014;12(2):303-12

14. Human Metabolome Database. Linoleic acid. Downloaded from http://www. hmdb.ca/spectra/nmr_one_d/1471 on Nov. 27, 2013.

15. Ragasa CY, Medecilo MP, Shen C-C. Chemical Constituents of Moringa oleifera Lam. Leaves. Der Pharma Chemica. 2015;7(7):395-399.

16. Ebajo VD Jr, Brkljaca R, Urban S, Ragasa CY. Chemical Constituents of Hoya buotii Kloppenb. J Appl Pharm Sci. 2015;5(11):69-72

\section{GRAPHICAL ABSTRACT}

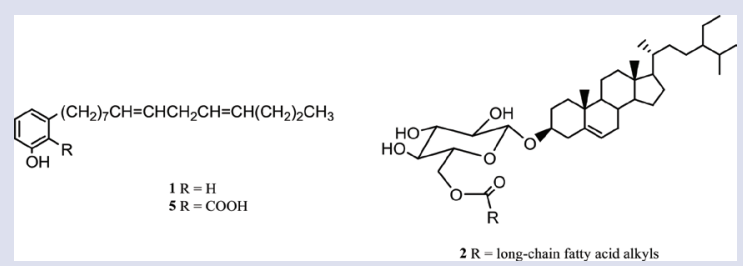

\section{HIGHLIGHTS OF PAPER}

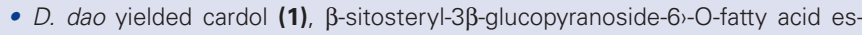
ters (2), $\beta$-sitosteryl fatty acid esters (3), and a mix $D$. dao yielded cardol (1), $\beta$-sitosteryl-3 $\beta$-glucopyranoside-6)-O-fatty acid esters (2), $\beta$-sitosteryl fatty acid esters (3), and a mixture of $\beta$-sitosterol (4a) and stigmasterol (4b) from the petiole; $\mathbf{1}$, a mixture of $\mathbf{4 a}$ and $\mathbf{4 b}$, anacardic acid (5), triacylglycerols (6), monoacylglycerol (7), long-chain fatty acid esters (8), and linoleic acid (9) from the twigs; and a mixture of $\mathbf{4 a}$ and $\mathbf{4 b}, \mathbf{5}, \mathbf{6}, \mathbf{8}$, long-chain fatty alcohols (10), and long- chain hydrocatbons (11) from the flowers of $D$. dao.

- The structures of $\mathbf{1}$ and $\mathbf{5}$ were elucidated by extensive 1D and 2D NMR spectroscopy, while those of 2-4 and 6-11 were identified by NMR spectroscopy.

\section{AUTHOR PROFILE}

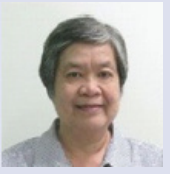

Consolacion Y. Ragasa: Obtained her Ph. D. in Chemistry from the University of the Philippines - Diliman. Dr. Ragasa is a Full Professor of the Chemistry Department and a University Fellow of De La Salle University - Manila. Her research focuses on the isolation and structure elucidation of the chemical constituents of Philippine plants. She has published extensively in natural products, phytochemistry and pharmacognosy journals. Dr. Ragasa was awarded the Pillar of Lasallian Excellence Award in Research (2013), National Research Council of the Philippines Achievement Award in Chemical Research (2003), Philippine Federation of Chemistry Societies Achievement Award in Chemical Research (2002), and St. Miguel Febres Cordero Research Award (SY 20002001). She is a member of the editorial board of several international and national journals.

Chien-Chang Shen: Is an Associate Research Fellow in Division of Chinese Medicinal Chemistry, National Research Institute of Chinese Medicine, Ministry of Health and Welfare, Taiwan, ROC.

Cite this article : Ragasa CY, Batarra TC, Vivar JLA, Reyes MMDL, Shen C. Chemical Constituents of Dracontomelon Dao (Blanco) Merr. et Rolfe. Pharmacog J. 2017;9(5):654-6. 